日臨外会誌 $65(6), 1588-1591,2004$

症 例

特異的肉眼形態を呈した小腸原発 MALT リンパ腫の 1 例

慈愛会今村病院外科, 鹿児島大学大学院医歯学総合研究科先進治療科学専攻腫惶学講座腫湯制御学 - 消化器外科学*

$$
\begin{array}{llllllll}
\text { 有 } & \text { 貴 } & \text { 明 } & \text { 川 崎 } & \text { 三 雄 } & \text { 上之園 芳 一 } \\
\text { 大 } & \text { 迫 } & \text { 保 } & \text { 愛 } & \text { 甲 } & \text { 孝* } & &
\end{array}
$$

小腸原発悪性リンパ腫は稀な疾患で，予後も不良とされている，その肉眼形態は多彩 であるが，動脈瘤様の拡張を呈するものは，そのほとんどが壁肥厚を伴い，粘膜には潰 瘍, 隆起性病変などの所見を認める。.今回, 腸管壁の菲薄化により, 動脈瘤様の㹡張を 呈し，粘膜面わよび漿膜面に所見がそしい小腸原発 MALT リンバ腫の1例を経験した ので報告する．症例は66歳，女性.タール便にて当院入院となり，小腸 X線検查で空腸 に動脈瘤椂拡張を認めた。開腹所見では空腸が限局性に動脈瘤様拡張を呈しており，空 腸部分切除術を行った。摘出標本の腸管環周は $21.5 \mathrm{~cm}$ と著明に拡張しており, 壁は菲薄 化し, 粘膜面は軽度のびらんを認めるのみであった. 病理組織学的に小腸原発 MALTリ ンパ腫と診断され，術後化学療法を行った． 4 年経過した現在でも無再発生存中である. 本症例は小腸 X線検査により病変が同定され，外科的治癒切除にて長期生存が可能とな った.

索引用語：小腸琹性リンパ腫, MALT リンパ腫, 動脈溜型

\section{緒言}

小腸原発悪性リンバ腫は比較的稀な疾患であり，そ の肉眼形態分類について，これまで統一された見解は 得られていない.一方, 胃原発悪性リンパ腫に比較し, その予後は極めて不良とされている゙。.今回，われわれ は特異的肉眼形態を呈した小腸原発 mucosa-associated lymphoid tissue (以下 MALT) リンパ嗹に 対し，手術を施行し，長期生存が得られた 1 例を経験 したので若干の文献的考察を加えて報告する。

$$
\text { 症例 }
$$

症例：66藏，女性。

主訴：タール便。

既往歴：大腿骨頸部骨折 (51歳時, 人工骨頭置換術)。 家族歴：特記すべきことなし。

現病歴：平成 8 年より当院内科で高血圧にて外来加 療中であった。平成11年9月27日頃よりタール便が出 現したため同年 10 月 2 日当科受晾入院となった。

2004年 1 月 8 日受付 2004 年 3 月17日採用

〈所属施設住所〉

テ 892-0824 鹿児島市堀江町17-1
入院時現症：身長 $146 \mathrm{~cm}$, 体重 $37 \mathrm{~kg}$, 体温 $36.8^{\circ} \mathrm{C}$, 血圧 $130 / 70 \mathrm{mmHg}$, 脈拍 90 回/分, 眼球結膜に黄涫㹥な く，眼瞼結膜に貧血を認めた，腹部には明らかな腫瘤 は触知されなかった。表在りンパ節は触知しなかった。

入院時血液検査成績：末梢血波検査では $\mathrm{Hb} 6.3 \mathrm{~g} /$ $\mathrm{dl}$ と高度な預血を認めた，白血球数，分画，生化学検 㚗に異常は認めなかった。腫場マーカーは正常で，抗 HTLV-1抗体は陰性であった（表 1).

胸部 X 線・CT 検查：縦隔内リンパ節の腫大は認め なかった。

腹部 CT・超音波検查 : 腹腔内リンパ節の腫大㧍上 び腫瘾像は認めなかった。

入院後経過：筫血に対し翰血（MAP 4 単位）を行 い, $\mathrm{Hb} 10.3 \mathrm{~g} / \mathrm{dl}$ まで改善し，その後は筫血の增悪もみ られなかった。タール便も消失したため，待機的に手 術を行う方針とした。

上部・下部消化管内視鏡検査：異常は認めなかった。 小腸 $\mathrm{X}$ 線検查：下部空腸に限局性の動脈瘤様掂張 を認めた（図 1).

以上より動脈瘤様に搪張した空腸からの出血を疑 い，同年10月13日開腹手術を施行した。 
表 1 入院時血液検査成績

\begin{tabular}{|c|c|c|c|c|c|}
\hline WBC & $6,900 / \mu \mathrm{I}$ & AST & $24 \mathrm{IU} / 1$ & BUN & $26.5 \mathrm{mg} / \mathrm{dl}$ \\
\hline $\mathrm{RBC}$ & $215 \times 10^{4} / \mu 1$ & ALT & $16 \mathrm{IU} / 1$ & $\mathrm{Cr}$ & $1.0 \mathrm{mg} / \mathrm{dl}$ \\
\hline $\mathrm{Hb}$ & $6.3 \mathrm{~g} / \mathrm{dl}$ & LDH & $426 \mathrm{IU} / 1$ & $\mathrm{Na}$ & $135 \mathrm{mEq} / \mathrm{l}$ \\
\hline $\mathrm{Ht}$ & $18.6 \%$ & ChE & $239 \mathrm{IU} / 1$ & $\mathrm{~K}$ & $4.7 \mathrm{mEq} / \mathrm{l}$ \\
\hline \multirow[t]{2}{*}{ PIT } & $19.5 \times 10^{4} / \mu 1$ & ALP & $269 \mathrm{IU} / 1$ & $\mathrm{Cl}$ & $97 \mathrm{mEq} / \mathrm{l}$ \\
\hline & & $\gamma \mathrm{GTP}$ & $13 \mathrm{IU} / 1$ & FBS & $114 \mathrm{mg} / \mathrm{dl}$ \\
\hline Stab & $10 \%$ & $\mathrm{~T}-\mathrm{Bil}$ & $1.05 \mathrm{mg} / \mathrm{dl}$ & $\mathrm{CRP}$ & $0.2 \mathrm{mg} / \mathrm{dl}$ \\
\hline Seg & $40 \%$ & D-Bil & $0.28 \mathrm{mg} / \mathrm{dl}$ & & \\
\hline Eosinc & $2 \%$ & AMY & $77 \mathrm{IU} / 1$ & CEA & $2.6 \mathrm{ng} / \mathrm{ml}$ \\
\hline Baso & $0 \%$ & $\mathrm{TP}$ & $6.4 \mathrm{~g} / \mathrm{dl}$ & CA19-9 & $11.1 \mathrm{U} / \mathrm{ml}$ \\
\hline Mono & $8 \%$ & Alb & $3.9 \mathrm{~g} / \mathrm{dl}$ & & \\
\hline Lymp & $39 \%$ & & & HTLV- & -IAb (-) \\
\hline
\end{tabular}

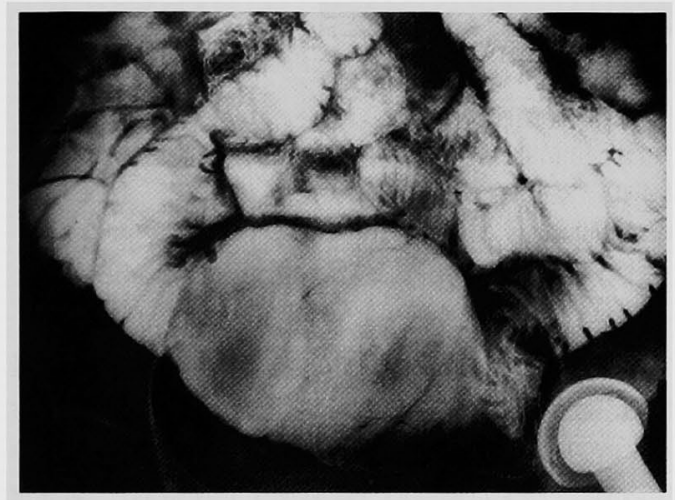

図 1 小腸 $\mathrm{X}$ 線検査：下部空腸に限局性の動脈瘤様拡張 を認めた。

手術所見：Treitz 靶帯から肛門側 $100 \mathrm{~cm}$ の空腸が 約 $20 \mathrm{~cm}$ にわたって限局性に動脈瘤様拡張を呈してお り，その近傍の小腸間膜にリンパ節腫大を認めた（図 2 ).手術は腫大したリンパ節を含めた拡張部位の空腸 部分切除術を施行した。

摘出標本所見：病変部は腸管環周 $21.5 \mathrm{~cm}$ と著明に 拡張しており，壁は菲薄化していた，粘膜面には出血 の原因と考えられるびらんを認めるのみであった（図 3)。嶈膜面には異常は認めなかった。

病理組織学的所見：全層にかけて小型から中型の異 型リンパ球のびまん性増殖および形質細胞への分化傾 向が認められ，粘膜面には lymphoepithelial lesion (LEL) の形成が認められた (図 4 a)，免疫組織化学 染色では B cell marker である CD79a 陽性 (図 4 b), T cell marker である CD3, CD5陰性であり (図 $4 \mathrm{c}$ ), in situ hybrization では $\lambda$ light chain 強陽性であった ことから MALT リンパ腫と診断した，同時に切除し

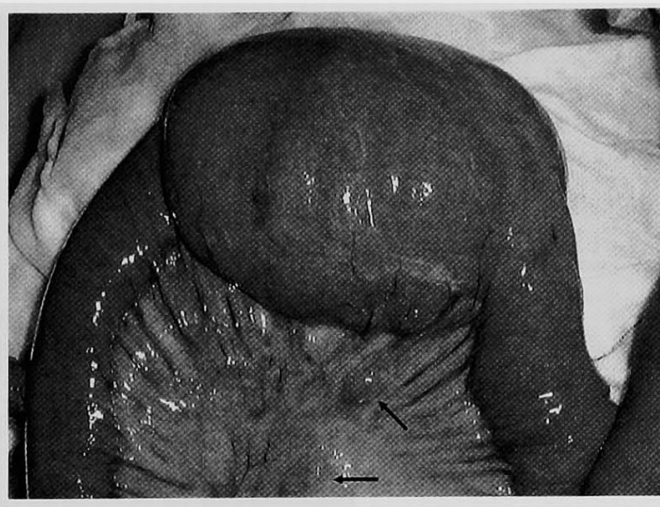

図 2 手術所見：Treitz 靶帯から $100 \mathrm{~cm}$ 肛門側の空腸が 約 $20 \mathrm{~cm}$ にわたって限局性に動脈瘤様拡張を呈してお り，その近傍の小腸間膜にリンパ節腫大を認めた（矢 印).

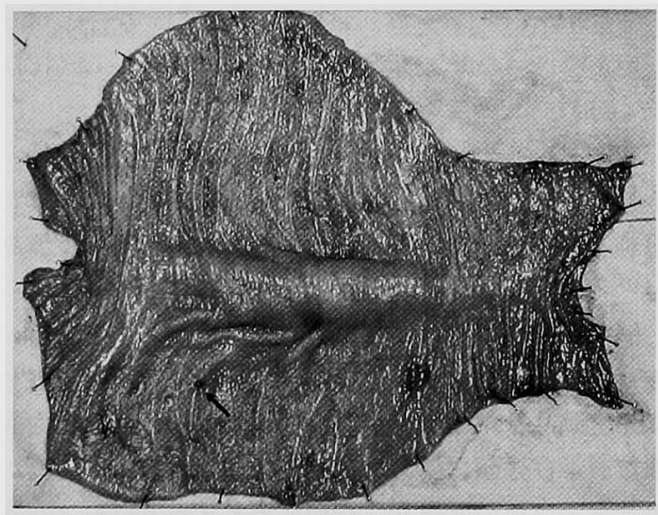

图 3 摘出標本 : 腸管環周 $21.5 \mathrm{~cm}$ と著明に拡張してお り，壁は菲薄化していた，粘膜面にはびらんを認める のみであった (矢印).

た腸間膜リンパ節にも転移を認めた。

以上のことから小腸原発の動脈㾇様拡張を呈する MALT リンパ腫と診断した。

術後経過：合併症はなく，経過は順調であった. Ga シンチグラフィーを施行したが，明らかな異常集積は 認めなかった。その後, 化学療法目的に当院血液内科 へ転科し, CHOP 療法 (シクロホスファマイド,アド リアマイシン，ビンクリスチン，プレドニゾロン）を 合計 9 クール施行し, 平成12年 2 月19日退院となった. 術後 4 年を経過した現在でも無再発生存中である.

考 察

全消化管悪性腫瘍における小腸原発悪性腫瘍の占め 


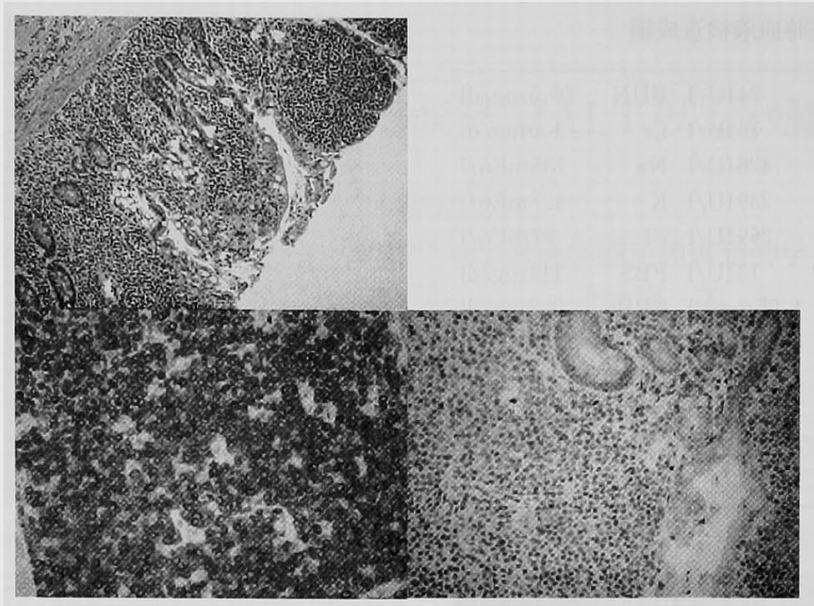

図 4 病理組織所見：a )小型から中型の異型リンパ球のびまん性增 殖および形質細胞への分化傾向が認められ，粘膜面には LEL の形 成が認められた (HE 染色, $\times 200)$ ，b ) B cell markerである CD79 a 陽性であった (CD79a 免疫染色, $\times 400)$ ，c） T cell marker で あるCD3陰性であった (CD3免疫染色, $\times 400)$.

る頻度は2.2〜3.2\%と稀な疾患であるが213)，このうち 悪性リンパ腫の割合は19〜38\% と比較的頻度が高 (ग) .

消化管原発悪性リンパ腫の診断基準として Dawson ら ${ }^{8)}$ は, (1)表在リンパ節が触知されない, (2)胸部X線写 真で縦滆リンパ節腫大がない, (3)末梢血液所見で白血 球数㧍よび分画に異常がない, (4)開腹手術時に病变が 腸管およびその所属りンパ節にとどまっている，(5)肝 臓と脾臓に転移がない，の 5 項目を満たすことを挙げ ている. 自験例も手術時に腸間膜リンパ節の腫大を認 めたが，所属りンパ節に限局しており小腸原発の悪性 リンパ腫として矛盾しない所見と考えられる。

初発症状としては腹痛が最も多く，このほかイレウ ス，嘔吐，下血などが多く認められるが特異的ではな い9．また小腸悪性リンパ腫の $24.8 \%$ に穿孔症例が認 められたとの報告があり ${ }^{91}$ ，小腸癌の $2.6 \%{ }^{99}$ に比較す ると高率であるために早期診断が重要であると考えら れる.一般に小腸病変の検索には内視鏡検查あるいは $\mathrm{X}$ 線検查が用いられており，本症例でも術前の小腸 $\mathrm{X}$ 線検查にて病変を指摘しえた。消化管出血が疑われ, 上部・下部消化管内視鏡検査にて異常が認められなか った場合には積極的に小腸病変の検索をする必要があ ると考えられる。

腸管悪性リンパ腫の肉眼形態分類について，これま
で統一された見解は得られていない.Wood ら101は,隆 起型, 動脈瘤型, 狭窄型, 潰湯型の 4 型に分類してお り, 渡辺ら ${ }^{11}$ は, 表面型, 隆起型, 潰湯型 (狭窄型·非 狭窄型)，びまん浸潤型 (狭窄型・非狭窄型)，多発ポ リポーシス型, 混合型の 6 つに分類している，自験例 は Wood ${ }^{100}$ の分類では動脈瘤型, 渡辺 ${ }^{11}$ の分類ではび まん浸潤型（非狭窄型）と考えられるが，その多くが 壁肥厚を伴い, 粘膜にも潰演, 隆起性病変などの所見 を認めるとされている，自験例の如く，壁の菲薄化に より動脈瘤様の拡張を呈し，粘膜面および漿膜面に所 見が乏しい小腸原発悪性リンパ腫の報告はわれわれが 検索した限りではなく, 非常に稀な肉眼形態と考えら れる.

小腸悪性リンパ腫の 5 年および10年生存率はそれぞ れ $55 \% ， 47 \%$ であり，胃悪性リンパ腫（5 年，10年生 存率 $76 \% ， 69 \%$ ）と比較すると有意に予後不良と言わ れている1!。一方で，中村ら '1外科的治癒切除例の 5 年生存率は $75 \%$ であるのに対し，非治癒切除ないし非 切除症例の 5 年生存率は $31 \%$ であり, 治癒切除が重要 であると報告している，また渡辺ら ${ }^{12)}$ は根治切除例で も術後の補助療法は必須であると報告している，自験 例でも外科的切除を行い，根治が得られたと考えられ たが，術後に化学療法を施行し， 4 年を経過した現在 でも無再発生存中である. 


\section{結 語}

腸管壁の菲薄化により，動脈㾕様の拡張を呈し，粘 膜面および漿膜面に所見がそしい小腸原発悪性リンパ 腫の1例を経験したので報告した。

$$
\text { 謝辞 }
$$

稿を終えるにあたり，病理組織学的所見について御指導 を頂きました今給黎総合病院病理検祖部の田代幸恵先生, 白濱 浩先生に深謝致します。

文 献

1）中村昌太郎，飯田三雄，竹下盛重他：小腸悪性》 ンパ腫の臨床病理学的特徵。胃と腸 $33: 383-$ 396, 1998

2）日本病理学会 (編)：日本病理剖娭輯報第 41 輯 (平 成10年度剖検例集録)，日本病理剖検辑報刊行会， $1104-1108,2000$

3) Martin R: Malignant tumors of the small intestine. Sur Clin Nortn Am 66:779--785, 1986

4) Naqvi MS, Burrows L, Kark AE: Lymphoma of the gastrointestinal tract. Ann Surg $170: 221$ $-231,1969$

5) Freeman C, Berg JW, Cutler SJ : Occurrence and prognosis of extranodal lymphoma. Cancer $29: 252-260,1972$
6）八尾恒良, 日吉雄一, 田中啓二他：最近10年間 （1970～1979）の本邦報告例の集計からみた空・

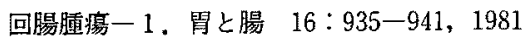

7) Radaszkiewicz $T$, Dragosics B, Baucr P: Gastrointestinal malignant lymphoma of the mucosa-associated lymphoid tissue. Gastroenterology $102: 1628-1638,1992$

8) Dawson IMP, Cornes JS, Morson BC : Primary malignant lymphoid tumors of the intestinal tract. Br J Surg 49:80-89, 1961

9）八尾恒良，八尾建史，真武弘明他：小腸脸湟一最 近 5 年間（1995 1999）の本邦報告例の集計．筒 と腸 $36: 871-881,2001$

10) Wood DA: Tumors of the intestine. In Atlas of Tumor Pathology, IV, AFIP, Washington DC, 1967, p22-98

11）渡辺英伸，丸田和夫，昧風洋一地：消化管墨性り ンパ腫の臟器別特性(病理学的見地から)。置と腸 $33: 299-308,1998$

12）渡辺美智夫，陳 利生，今井美和他：消化管覀性 リンパ腫の外科治療と予後。胃と腸 $33: 439-$ 445,1998

\title{
A CASE OF PRIMARY MALT LYMPHOMA OF THE SMALL INTESTINE WITH NOVEL MACROSCOPIC CHARACTERISTICS
}

\author{
Takaaki ARIGAMI, Yuzou KAWASAKI, Yoshikazu UENOSONO, \\ Tamotsu OHSAKO and Takashi AIKOU* \\ Department of Surgery, Jiaikai Imamura Hospital \\ *Surgical Oncology, Digestive Surgery, Kagoshima University School of Medicine
}

Primary MALT lymphoma of the small intestine is rare, and is associated with a poor prognosis. There are many macroscopic types, but almost all lymphomas of the small intestine with aneurysmal dilatation have thick walls, ulcerative lesions and elevated lesions in the mucosa. A case of primary MALT lymphoma of the small intestine with novel macroscopic characteristics is reported. A 66-yearold woman was admitted because of tarry stools. Fluoroscopic examination of the small intestine showed local aneurysmal dilatation in the jejunum, and surgery was performed. During laparotomy, aneurysmal dilatation was seen in the jejunum, and a partial jejunectomy with lymph node dissections was performed. Macroscopically, the resected jejunum was $21.5 \mathrm{~cm}$ in length and exhibited thin walls and erosive lesions only in the mucosa. The pathological diagnosis was primary mucosa-associated lymphoid tissue (MALT) lymphoma of the small intestine. After surgery, the patient was given chemotherapy and there have been no signs of recurrence 4 years post-operatively. 